\title{
PENERAPAN MODEL PEMBELAJARAN KOOPERATIF TEKNIK JIGSAW BERBANTU MEDIA KARTU UNTUK MENINGKATKAN AKTIVITAS DAN HASIL BELAJAR AKUNTANSI
}

\section{THE IMPLEMENTATION OF COOPERATIVE LEARNING MODEL USING JIGSAW TECHNIQUE WITH CARDS MEDIA ASSISTED TO IMPROVE ACCOUNTING LEARNING ACTIVITIES AND OUTCOMES}

\author{
Oleh: \\ Sri Maida Astuti \\ Mahasiswa Pendidikan Akuntansi Universitas Negeri Yogyakarta \\ astutimaida@yahoo.com
}

\begin{abstract}
Abstrak
Penelitian ini merupakan penelitian tindakan kelas yang bertujuan untuk meningkatkan Aktivitas Belajar dan Hasil Belajar Akuntansi siswa kelas X Akuntansi 1 SMK Koperasi Yogyakarta tahun ajaran 2013/2014 melalui Penerapan Model Pembelajaran Kooperatif Teknik Jigsaw berbantu Media Kartu. Penelitian ini dilaksanakan secara kolaboratif selama dua sikilus, untuk masing-masing siklus dilaksanakan selama dua pertemuan. Teknik pengumpulan data penelitian ini adalah observasi partisipatif, dokumentasi, dan tes.Teknik analisis data yang digunakan adalah deskripsi kuntitatif. Berdasarkan hasil penelitian disimpulkan bahwa Model Pembelajaran Kooperatif Teknik Jigsaw berbantu Media Kartu dapat meningkatkan Aktivitas Belajar dan Hasil Belajar Akuntansi siswa kelas X Akuntansi 1 SMK Koperasi Yogyakarta tahun ajaran 2013/2014.Hasil penelitian menunjukkan bahwa telah terjadi peningkatan Aktivitas Belajar dan Hasil Belajar Akuntansi setelah dilakukan tindakan. Aktivitas Belajar siswa secara keseluruhan meningkat dari siklus I yang semula 53,89\% meningkat menjadi $77,27 \%$ pada siklus II. Siswa yang mengalami peningkatan skor aktivitas sebesar 90,91\%. Hasil Belajar Akuntansi juga mengalami peningkatan. Siswa yang mencapai nilai KKM pada siklus I sebesar 23,81\% meningkat menjadi $80,00 \%$ pada siklus II.
\end{abstract}

Kata kunci: Jigsaw, Media Kartu, Aktivitas, Hasil Belajar Akuntansi

\begin{abstract}
This research belongs to classroom action research which aimed at improving Accounting Learning Activities and Outcomes of the students of class X Accounting 1, Koperasi Vocational High School of Yogyakarta academic year 2013/2014 through the implementation of Cooperative Learning Model using Jigsaw technique with Cards Media-assisted. This study was conducted in the form of collaborative research and carried out in two cycles in which each cycle was performed in two meetings. The data collection techniques were participatory observation, documentation, and test. In addition, descriptive quantitative technique was used to analyze the data. Based on the research findings, it can be concluded that the implementation of Cooperative Learning Model using Jigsaw Technique with Cards Media-assisted can improve Accounting Learning Activities and Outcomes of the students of class X Accounting 1, Koperasi Vocational High School of Yogyakarta academic year 2013/2014. The research findings show that the students' Accounting Learning Activities and Outcomes have improved after the model was implemented. The overall students' learning activities whose original score was $53.89 \%$ in the first cycle has increased to $77.27 \%$ in the second cycle. It can also be said that there are $90.91 \%$ of the students who have increased their activity score. Furthermore, the students' Accounting Learning Outcomes also increased. In the first cycle, $23.81 \%$ of the total students could reach the minimum passing-grade criteria. The number of the students who can reach the minimum criteria has increased to $80.00 \%$ in the next cycle.
\end{abstract}




\section{PENDAHULUAN}

Pendidikan merupakan suatu upaya yang dilakukan untuk membekali manusia dengan ilmu, rasa, dan keterampilan agar dapat hidup dengan keadaan yang lebih baik. Pendidikan telah banyak memberikan kontribusi dalam kehidupan manusia. Dalam pembukaan Undang-undang Dasar 1945 disebutkan bahwa salah satu tujuan pendidikan di Indonesia adalah untuk mencerdaskan kehidupan bangsa. Berdasarkan hal tersebut maka wajar jika masalah pendidikan selalu menjadi fokus perhatian oleh berbagai pihak terutama oleh pemerintah. Berbagai upaya dilakukan untuk meningkatkan mutu Pendidikan Nasional. Baik tidaknya kualitas pendidikan salah satunya dapat diamati dari hasil belajar peserta didik.

Usaha untuk meningkatkan hasil belajar peserta didik bukanlah suatu usaha yang mudah. Hasil belajar dapat dijadikan tolok ukur untuk mengetahui keberhasilan belajar peserta didik berupa penguasaan aspek kognitif, afektif, dan psikomotor pada suatu mata diklat tertentu. Guru sebagai pengelola proses pembelajaran hendaknya berusaha menciptakan kondisi belajar mengajar yang kondusif untuk menarik keaktifan siswa. Guru dituntut untuk kreatif dan inovatif dalam menciptakan kondisi belajar mengajar agar materi yang disampaikan dapat diterima siswa dengan baik.

Faktor yang mempengaruhi Hasil Belajar Akuntansi sangatlah beragam. Faktor itu bisa berasal dari faktor internal atau faktor yang berasal dalam diri siswa dan faktor eksternal atau faktor yang berasal dari luar diri siswa. Guru harus memahami kondisi siswa selama pembelajaran.

Menurut Oemar Hamalik (2005:172), belajar tidak cukup hanya mendengar dan melihat tetapi harus dengan melakukan aktivitas yang lain diantaranya membaca, bertanya, menjawab, berpendapat, mengerjakan tugas, presentasi, diskusi, menyimpulkan. Berdasar hal tersebut, maka dalam proses belajar mengajar sangat diperlukan adanya aktivitas untuk menunjang kelancaran kegiatan belajar dalam rangka meningkatkan hasil belajar siswa.

Sekolah adalah salah satu pusat kegiatan belajar, dengan demikian, di sekolah merupakan arena untuk mengembangkan aktivitas baik aktivitas secara fisik maupun nonfisik. Dimyati dan Mudjono (2009:45) menyebutkan bahwa aktivitas itu beraneka ragam bentuknya yaitu berupa kegiatan fisik dan kegiatan psikis. Sardiman (2011:100) mengemukakan bahwa aktivitas belajar adalah aktivitas yang bersifat fisik dan mental. Pembelajaran akan berjalan dengan baik apabila dapat mengaitkan kedua aktivitas tersebut.

Hasil observasi di kelas X Akuntansi 1 SMK Koperasi Yogyakarta pada tanggal 16 September 2013 menunjukkan siswa kurang aktif selama proses belajar mengajar berlangsung. Metode ceramah yang diterapkan oleh guru kurang mampu meningkatkan keaktifan dan hasil belajar siswa. Hal itu ditunjukkan dengan $80 \%$ perhatian siswa terhadap pelajaran masih rendah. Ketika guru menerangkan siswa memilih berbincang-bincang dengan teman sebangku membicarakan hal-hal di luar materi. Apabila guru memberikan pertanyaan maka siswa menjawab "tidak bisa". Apabila guru mempersilahkan siswa untuk bertanya, siswa cenderung tidak bertanya. Hal tersebut berpengaruh terhadap Hasil Belajar Akuntansi siswa. Berdasarkan nilai Ujian Tengah Semester menunjukan jumlah siswa yang mencapai nilai Kriteria Ketuntasan Minimal (KKM) sebesar $28,6 \%$ atau 7 dari jumlah keseluruhan 22 siswa. Siswa yang belum mencapai nilai KKM sebanyak 15 siswa atau sebesar $71,4 \%$. Berdasarkan 
wawancara dengan guru, selama ini guru belum menggunakan model pembelajaran yang bervariasi. Model yang diterapkan guru adalah ceramah dan tanya jawab. Hal itu menyebabkan siswa kurang aktif dan tidak tertarik untuk mengikuti pelajaran sehingga proses pembelajaran menjadi berpusat pada guru. Oleh karena itu perlu dicari pemecahannya, supaya tidak menimbulkan masalah-masalah lain yang akhinya menyebabkan tujuan pembelajaran tidak tercapai. Salah satu upaya untuk meningkatkan Aktivitas dan Hasil Belajar Akuntansi dengan menerapkan model pembelajaran yang menarik dan menuntut aktivitas siswa.

Model pembelajaran yang dapat digunakan salah satunya adalah Model Pembelajaran Kooperatif. Eggen dan Kauchak dalam Trianto (2010: 58) menyebutkan pembelajaran kooperatif sebagai sebuah kelompok strategi pengajaran yang melibatkan siswa bekerjasama secara berkolaborasi untuk mencapai tujuan bersama. "Melalui pembelajaran kooperatif akan memberi kesempatan pada siswa untuk bekerja sama dengan sesama siswa lainnya dalam tugastugas yang terstruktur" (Made Wena, 2010: 189). Melalui pembelajaran kooperatif diharapkan siswa dapat aktif dalam proses pembelajaran, dapat mengeluarkan ide, gagasan sesuai kemapuan masing-masing akan belajar untuk bertanggungjawab dan menemukan solusi atas masalah yang dihadapi.

Salah satu jenis model pembelajaran kooperatif adalah teknik Jigsaw. Jigsaw pertama kali dikembangkan dan diujicobakan oleh Elliot Aronson dan teman-teman di Universitas Texas. Menurut Slavin (2009: 146) Jigsaw merupakan salah satu model pembelajaran kooperatif yang paling fleksibel. Teknik ini dapat pula digunakan dalam berbagai mata pelajaran, seperti: IPA, IPS, Matematika, Agama, dan Bahasa (Anita Lie, 2010: 69). Jika dipahami, maka teknik ini cocok untuk semua kelas atau tingkatan. Tujuan diciptakannya model pembelajaran kooperatif Jigsaw ini adalah untuk meningkatkan rasa tanggungjawab siswa terhadap belajarnya sendiri dan juga belajar anggota kelompoknya yang lain. Setiap siswa dalam model pembelajaran kooperatif ini adalah anggota dari dua kelompok, yaitu kelompok asal (home group) dan kelompok ahli (expert group).

Aktivitas belajar siswa juga dapat tercipta dari kondisi belajar mengajar yang menyenangkan. Penerapan model pebelajaran kooperatif teknik Jigsaw perlu didukung oleh media pembelajaran yang dapat meningkatkan Aktivitas Belajar siswa dalam pembelajaran sehingga suasana belajar menjadi lebih menyenangkan dan tidak membosankan. Zainal Aqib (2001: 58) menyebutkan media pengajaran diartikan sebagai segala sesuatu yang dapat digunakan untuk menyalurkan pesan, merangsang pikiran, perasaan, perhatian, kemauan siswa, sehingga dapat mendorong proses belajar. "Media merupakan bentuk-bentuk komunikasi baik tercetak maupun audiovisual serta peralatannya" (Azhar Arsyad, 2011: 3). Media digunakan untuk membantu siswa belajar supaya tidak terasa membosankan dan meningkatkan Aktivitas, sehingga Hasil Belajar Akuntansi juga dapat ditingkatkan.

Salah satu media yang dapat digunakan dalam pembelajaran Akuntansi adalah media kartu. Menurut Kamus Besar Bahasa Indonesia (2005: 448) kartu adalah kertas tebal yang berbentuk persegi panjang. Kartu dapat diartikan sebagai kertas tebal, berbentuk segi empat, berisi materi yang akan disampaikan oleh guru, bisa berupa gambar, keterangan gambar, pertanyaan, jawaban, tergantung dari kreativitas guru dalam proses pembelajaran. Kartu merupakan media pembelajaran karena di dalam kartu terdapat informasi yang berisi mengenai materi yang akan disampaikan oleh guru. 
Media Kartu yang digunakan dalam penelitian ini adalah kartu yang berisi pertanyaan-pertanyaan dari materi yang disampaikan oleh guru, kartu jawaban, dan kartu kunci jawaban. Penggunaan media kartu ini yang dikolaborasikan dengan metode pembelajaran kooperatif teknik Jigsaw diharapkan dapat menimbulkan kegembiraan dan dapat memberikan semangat bagi siswa untuk mengikuti proses pembelajaran. Siswa merasa tertarik dan mau berpartisipasi aktif tanpa adanya tekanan sehingga dapat mengurangi atau menghilangkan kejenuhan dan rasa bosan siswa. Adanya peningkatan partisipasi atau peningkatan Aktivitas Belajar siswa dalam pembelajaran tersebut diharapkan dapat meningkatkan Hasil Belajar Akuntansi siswa.

Sesuai dengan analisis situasi yang telah disebutkan, peneliti bermaksud melakukan penelitian tindakan kelas dengan judul "Penerapan Model Pembelajaran Kooperatif Teknik Jigsaw Berbantu Media Kartu untuk Meningkatkan Aktivitas dan Hasil Belajar Akuntansi Siswa Kelas X Akuntansi 1 di SMK Koperasi Yogyakarta Tahun Ajaran 2013/2014".

\section{METODE PENELITIAN Desain Penelitian}

Jenis penelitian ini adalah Penelitian Tindakan Kelas (Classroom Action Research). Menurut Suharsimi Arikunto (2009: 3) Penelitian tindakan kelas merupakan suatu pencermatan terhadap kegiatan belajar berupa sebuah tindakan yang sengaja dimunculkan dan terjadi dalam sebuah kelas secara bersama. Prosedur yang digunakan adalah proses penelitian tindakan model Kemmis dan Taggart, selama 2 siklus. Penelitian ini dilaksanakan secara kolaboratif antara peneliti dengan guru pelajaran Akuntansi.

\section{Waktu dan Tempat Penelitian}

Penelitian dilakukan di Kelas X Akuntansi 1 SMK Koperasi Yogyakarta yang beralamat di Jalan Kapas I No 5 Yogyakarta. Penelitian dilakukan meliputi tahap persiapan pada bulan Oktober 2013. Tahap pelaksanaan sampai tahap pelaporan yaitu pada bulan November 2013 hingga Januari 2014.

\section{Subjek dan Objek Penelitian}

Subjek penelitian ini adalah seluruh siswa kelas X Akuntansi 1 SMK Koperasi Yogyakarta tahun ajaran 2013/2014 sejumlah 22 siswa, sedangkan objek penelitian ini adalah Penerapan Model Pembelajaran Kooperatif Tipe Jigsaw Berbantu Media Katu untuk meningkatkan Aktivitas dan Hasil Belajar Akuntansi.

\section{Prosedur Penelitian}

Penelitian ini akan dilakukan secara kolaboratif dengan guru mata pelajaran akuntansi kelas X Akuntansi 1 SMK Koperasi Yogyakarta selama dua siklus. Masing-masing siklus terdiri dari empat tahap, yaitu perencanaan, pelaksanaan, pengamatan dan refleksi. Adapun prosedur pelaksanaannya adalah sebagai berikut:

\section{Siklus I}

a. Tahap Perencanaan tindakan

1) Menyusun Rencana Pelaksanaan Pembelajaran (RPP) tentang materi Membukukan Jurnal Penyesuaian dengan Penerapan Model Pembelajaran Kooperatif Teknik Jigsaw Berbantu Media Kartu.

2) Membuat hand out untuk siswa tentang Membukukan Jurnal Penyesuaian.

3) Menyiapkan Media Kartu untuk pembelajaran membukukan Jurnal Penyesuaian, dan lembar observasi.

4) Menyusun soal pre-test dan posttest siklus I dan siklus II tentang jurnal penyesuaian.

b. Tahap Pelaksanaan Tindakan 
Pelaksanaan tindakan ini merupakan implementasi dari isi rancangan. Pada penelitian ini adalah penerapan Pembelajaran Kooperatif Teknik Jigsaw Berbantu Media Kartu. Pelaksanaan tindakan ini dilaksanakan oleh guru selaku tenaga pengajar dengan berpedoman pada Rencana Pelaksanaan Pembelajaran (RPP) yang telah dibuat sebelumnya. Pelaksanaan tindakan ini bersifat fleksibel, yaitu disesuaikan dengan kondisi dan keadaan di kelas, dapat berubah sewaktu-waktu disesuaikan dengan keadaan di lapangan.

c. Tahap Pengamatan

Tahap pengamatan dilakukan bersama dengan tahap pelaksanaan, karena tahap pengamatan dilakukan ketika tindakan sedang dilakukan. Kegiatan yang dilakukan pada tahap ini adalah peneliti bersama dengan observer mengamati jalannya proses belajar mengajar yang sedang berlangsung, sekaligus mengamati bagaimana aktivitas belajar siswa untuk dapat diketahui data mengenai aktivitas belajar. Peneliti mengamati dan mencatat hal-hal yang terjadi selama proses pembelajaran yang berkaitan dengan aktivitas belajar.

d. Tahap Refleksi

Tahap refleksi dilakukan setelah pelaksanaan tindakan dan pengamatan. Refleksi dilakukan bersama-sama antara guru dan peneliti. Kegiatan ini dilakukan untuk mengkaji proses pembelajaran yang telah berlangsung pada siklus I. Hasil refleksi siklus I akan digunakan sebagai masukan dan perbaikan untuk perencanaan siklus selanjutnya sehingga pelaksanaan pembelajaran siklus selanjutnya diharapkan lebih baik dari siklus sebelumnya dan dapat mencapai indikator keberhasilan tindakan.

\section{Siklus II}

a. Tahap Perencanaan Tindakan

Tahap perencanaan pada siklus II ini kegiatannya hampir mirip dengan siklus I, hanya saja pada siklus II ini merupakan perbaikan dari siklus I berdasarkan hasil refleksi yang dilakukan. Tahap perencanaan siklus II ini peneliti menyusun Rencana Pelaksanaan Pembelajaran (RPP), membuat hand out, media kartu untuk pembelajaran, menyusun soal pre-test dan post-test siklus II mengenai jurnal penyesuaian.

b. Tahap Pelaksanaan Tindakan

Hampir sana dengan siklus I, pelaksanaan tindakan dilaksanakan setelah tahap persiapan selesai dilakukan. Pelaksanaan tindakan ini dilaksanakan oleh guru selaku tenaga pengajar dengan berpedoman pada Rencana Pelaksanaan Pembelajaran (RPP) yang telah dibuat sebelumnya. Pelaksanaan ini bersifat fleksibel, yaitu disesuaikan dengan kondisi dan keadaan di kelas, dapat berubah sewaktu-waktu disesuaikan dengan keadaan di lapangan.

c. Tahap Pengamatan

Tahap pengamatan dilakukan bersamaan dengan pelaksanaan, karena pada saat guru melaksanakan pembelajaran, peneliti bersama observer juga melakukan pengamatan. Kegiatan pengamatan dilakukan dengan mencatat semua hal yang terjadi selama pelaksanaan tindakan berlangsung. Peneliti mengamati Aktivitas Belajar siswa selama proses pembelajaran untuk mendapatkan data mengenai Aktivitas Belajar.

d. Tahap Refleksi

Tahap refleksi dilakukan untuk mengkaji secara menyeluruh tindakan yang telah dilakukan berdasarkan data pada siklus II. Refleksi dilakukan bersama dengan 
guru Akuntansi dengan berpedoman pada hasil siklus II. Jika terdapat masalah dari proses refleksi selama siklus II, maka dilakukan perbaikan melalui siklus berikutnya sehingga siklus berikutnya dapat lebih baik lagi.

Teknik Pengumpulan Data

\section{Observasi}

"Observasi adalah teknik pengumpulan data yang digunakan untuk menghimpun data penelitian melalui pengamatan dan pengindraan" (Burhan Bungin, 2007: 115). Data mengenai Aktivitas Belajar diperoleh secara langsung oleh peneliti. Observasi digunakan untuk mengetahui Aktivitas Belajar melalui Penerapan Model Pembelajaran Teknik Jigsaw Berbantu Media Kartu. Hasil observasi selanjutnya dicatat pada lembar observasi yang sudah disediakan.

2. Tes

"Tes adalah alat atau prosedur yang digunakan untuk mengetahui atau mengukur sesuatu dalam suasana dengan cara dan aturan-aturan yang sudah ditentukan" (Suharsimi Arikunto, 2007: 53). Tes pada penelitian ini digunakan untuk mengetahui peningkatan hasil belajar siswa dari aspek kognitif.

\section{Dokumentasi}

Dokumentasi pada penelitian ini diantaranya, peneliti menyelidiki benda-benda tertulis seperti buku, data siswa, buku prestasi siswa. Dokumentasi ini digunakan untuk mengetahui data siswa sebagai dasar untuk pembentukan kelompok dan silabus untuk acuan pembuatan Rencana Pelaksanaan Pembelajaran (RPP).

\section{Instrumen Penelitian}

\section{Pedoman Observasi}

Lembar observasi digunakan sebagai pedoman untuk melakukan pengamatan guna mendapatkan data yang ingin diketahui oleh peneliti terkait Aktivitas Belajar. Terdapat tujuh indikator ktivitas yang diamati. Masingmasing siswa diamati menggunakan lembar obserbasi. Pengamatan ditulis dengan cara mencatat munculnya indikator selama proses pembelajaran dan memberikan skor sesuai kategori Dalam penelitian ini alternatif skor yaitu 0,1 dan 2 .

2. Tes

Instrumen tes digunakan untuk mengukur peningkatan Hasil Belajar Akuntansi siswa setelah mengikuti proses belajar mengajar dari aspek kognitif. Penilaian dilakukan dengan melakukan pre test dan post test pada tiap siklus. Pre test dan post test berisi materi yang sedang dibahas. Tes yang dipakai pada siklus I berupa pertanyaan pilihan ganda yang berjumlah 15 soal, dan untuk siklus II berupa soal essay yang berjumlah 8 soal. Nilai pre test siklus I akan dibandingkan dengan nilai post test siklus I untuk mengetahui peningkatannya dan post test siklus I akan dibandingkan dengan post test siklus II.

\section{Teknik Analisis Data}

Wina Sanjaya (2011: 106) mengemukakan analisis data diarahkan untuk mencari dan menemukan upaya yang dilakukan oleh guru/peneliti dalam meningkatkan kualitas proses dan hasil belajar siswa. Analisis yang digunakan untuk mengolah data pada penelitian ini menggunakan data kuantitif. Data kuantitatif digunakan untuk menganalisis data berdasarkan hasil pengamatan Aktivitas Belajar dan Hasil Belajar Akuntansi. Data Aktivitas diperoleh dari lembar observasi dan data mengenai Hasil Belajar Akuntansi diperoleh berdasarkan tes. 


\section{Analisis Aktivitas Belajar}

Analisis data Aktivitas dapat dihitung menggunakan rumus:

a) $\%$ Aktivitas belajar Individu $=\frac{\sum \text { skor indikator yang muncul }}{\text { skor maksimal ideal }} \times 100 \%$

b) $\%$ Aktivitas Belajar tiap indikator $=$ $\frac{\sum \text { skor siswa yang aktif }}{\text { skor maksimal ideal }}$ X 100\%

2. Analisis Hasil Belajar Akuntansi

Analisis Hasil Belajar Akuntansi dapat dihitung dengan rumus:

$$
\mathrm{P}=\frac{F}{N} \mathrm{X} 100 \%
$$

(Djamarah, 2010: 264)

Keterangan:

$\mathrm{P}=$ Persentase siswa yang tuntas

$\mathrm{F}=$ Siswa yang memperoleh nilai $\geq 75$

$\mathrm{N}=$ Jumlah siswa yang mengikuti tes

\section{Indikator Keberhasilan}

Penelitian ini dikatakan berhasil apabila terdapat perubahan yang lebih baik setelah dilakukannya tindakan melalui Model Pembelajaran Teknik Jigsaw Berbantu Media Kartu. Mulyasa (2006: 101) mengatakan bahwa pembelajaran dikatakan berhasil dan berkualitas apabila sebagian besar $(75 \%)$ siswa terlibat aktif dalam proses pembelajaran. Kriteria keberhasilan penelitian ini adalah sebagai berikut:

\section{a. Aktivitas Belajar}

Penelitian berhasi ditandai dengan persentase Aktivitas Belajar secara keseluruhan mencapai lebih dari $75 \%$, secara individu siswa yang mengalami peningkatan Aktivitas Belajar mencapai lebih dari $75 \%$.

\section{b. Hasil Belajar Akuntansi}

Hasil Belajar Akuntansi siswa aspek kognitif mengalami peningkatan minimal $75 \%$. Artinya siswa yang mencapai nilai Kriteria Ketuntasan Minimal (KKM) minimal $75 \%$ dari jumlah siswa yang mengikuti tes pada mata diklat Akuntansi.

\section{HASIL PENELITIAN DAN PEMBAHASAN \\ a. Aktivitas Belajar}

Aktivitas Belajar pada siklus I belum semuanya mencapai keberhasilan tindakan. Hanya indikator kerjasama dalam kelompok saja yang mencapai keberhasilan tindakan75\%. Berdasarkan hasil tersebut, maka diperlukan perbaikan pada siklus II supaya aktivitas belajar siswa dapat meningkat dan mencapai kriteria keberhasilan. Cara yang digunakan untuk mengatasi masalah tersebut adalah dengan memberikan kesempatan yang lebih banyak kepada siswa untuk berdiskusi dalam kelompok, selain itu perlu adanya arahan dan bimbingan dari guru selama proses pembelajaran. Hal ini terbukti dengan adanya peningkatan Aktivitas belajar siswa dari siklus I sebesar $53,89 \%$ meningkat menjadi $77,27 \%$ pada siklus II. Masing-masing indikator juga mengalami peningkatan. Dan 20 siswa atau 90,91\% siswa mengalami peningkatan skor Aktivitas Belajar. Untuk lebih jelasnya, berikut ini adalah tabel yang menunjukkan peningkatan Aktivitas Belajar kelas X Akuntansi 1:

Tabel 1. Peningkatan

Persentase Aktivitas Belajar

\begin{tabular}{|c|c|c|c|}
\hline $\begin{array}{l}\mathrm{N} \\
\mathrm{O}\end{array}$ & $\begin{array}{l}\text { Indikator } \\
\text { Aktivitas Belajar }\end{array}$ & $\begin{array}{l}\text { SIKLUS } \\
\text { I }\end{array}$ & $\begin{array}{l}\text { SIKLUS } \\
\text { II }\end{array}$ \\
\hline 1 & $\begin{array}{l}\text { Membaca materi } \\
\text { akuntansi }\end{array}$ & $65,91 \%$ & $77,27 \%$ \\
\hline 2 & $\begin{array}{l}\text { Mendengar dan } \\
\text { mencatat } \\
\text { materi/penjelasan } \\
\text { guru }\end{array}$ & $63,64 \%$ & $77,27 \%$ \\
\hline 3 & $\begin{array}{l}\text { Bertanya kepada } \\
\text { guru/teman }\end{array}$ & $43,18 \%$ & $81,82 \%$ \\
\hline 4 & $\begin{array}{l}\text { Menjawab } \\
\text { pertanyaan }\end{array}$ & $36,36 \%$ & $65,91 \%$ \\
\hline 5 & $\begin{array}{l}\text { Kerjasama dalam } \\
\text { kelompok }\end{array}$ & $70,45 \%$ & $86,36 \%$ \\
\hline 6 & Menanggapi & $34,09 \%$ & $63,64 \%$ \\
\hline
\end{tabular}




\begin{tabular}{|l|l|c|c|}
\hline $\begin{array}{l}\mathrm{N} \\
\mathrm{o}\end{array}$ & $\begin{array}{l}\text { Indikator } \\
\text { Aktivitas Belajar }\end{array}$ & $\begin{array}{c}\text { SIKLUS } \\
\mathrm{I}\end{array}$ & $\begin{array}{c}\text { SIKLUS } \\
\text { II }\end{array}$ \\
\hline & $\begin{array}{l}\text { jawaban/pendapa } \\
\text { t teman }\end{array}$ & & \\
\hline 7 & $\begin{array}{l}\text { Mengerjakan tes } \\
\text { dengan } \\
\text { kemampuan } \\
\text { sendiri }\end{array}$ & $63,64 \%$ & $88,64 \%$ \\
\hline \multicolumn{2}{|c|}{ Rata-rata } & $\mathbf{5 3 , 8 9 \%}$ & $\mathbf{7 7 , 2 7 \%}$ \\
\hline
\end{tabular}

Peningkatan persentase Aktivitas Belajar untuk siklus I dan siklus II dapat disajikan pada grafik berikut ini:

\section{Grafik Peningkatan}

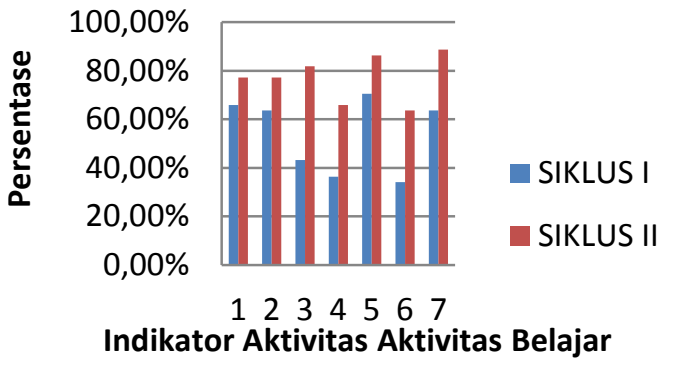

Gambar 1. Diagram Batang Peningkatan Aktivitas Belajar Siswa Siklus I dan Siklus II

Keterangan:

1 : Membaca materi akuntansi

2 : Mengerjakan tes dengan kemampuan sendiri

3 : Mendengar dan mencatat materi/penjelasan guru

4 : Bertanya kepada guru/teman

$5:$ Menjawab pertanyaan

6 : Kerjasama dalam kelompok

7 : Menanggapi jawaban/pendapat teman

Berdasarkan data di atas maka dapat diketahui bahwa indikator membaca materi akuntansi mengalami peningkatan sebesar $11,36 \%$. Mendengar dan mencatat materi/penjelasan guru meningkat sebesar $13,63 \%$. Indikator bertanya kepada guru/teman mengalami peningkatan sebesar 38,64\%. Indikator menjawab pertanyaan mengalami peningkatan cukup tinggi yaitu $29,55 \%$. Indikator kerjasama dalam kelompok mengalami peningkatan $15,91 \%$. Indikator menanggapi jawaban/pendapat teman ini sangat tinggi yaitu $29,55 \%$, dan indikator mengerjakan tes dengan kemampuan sendiri memperoleh persentase sebesar $25,00 \%$.

\section{b. Hasil Belajar Akuntansi}

Hasil Belajar Akuntansi pada siklus I belum mencapai kriteria bekerhasilan tindakan. Siswa yang mencapai nilai KKM hanya $23,89 \%$. oleh karena itu diperlukan perbaikan pada siklus II dan ternyata terjadi peningkatan Hasil Belajar siswa. Siswa yang mencapai nilai KKM pada siklus II mencapai $80,00 \%$. Berikut ini disajikan tabel peningkatan Hasil Belajar Akuntansi siswa dari siklus I ke siklus II.

\begin{tabular}{|c|c|c|c|c|c|c|}
\hline \multirow{2}{*}{$\begin{array}{l}\mathrm{Si} \\
\mathrm{kl} \\
\text { us }\end{array}$} & \multirow{2}{*}{$\begin{array}{c}\text { keteran } \\
\text { gan }\end{array}$} & \multirow{2}{*}{$\begin{array}{c}\mathrm{Jm} \\
1 \\
\text { sis } \\
\text { wa }\end{array}$} & \multicolumn{2}{|c|}{$\begin{array}{l}\text { Nilai } \\
\text { siswa }\end{array}$} & \multicolumn{2}{|c|}{ Persentase } \\
\hline & & & $<75$ & $\begin{array}{l}\geq 7 \\
5\end{array}$ & $<75$ & $\geq 75$ \\
\hline \multirow{2}{*}{ I } & $\begin{array}{l}\text { Pre } \\
\text { Test }\end{array}$ & 20 & 20 & 0 & $100 \%$ & $0 \%$ \\
\hline & $\begin{array}{l}\text { Post } \\
\text { Test }\end{array}$ & 21 & 16 & 5 & $76,19 \%$ & $23,81 \%$ \\
\hline \multirow{2}{*}{ II } & $\begin{array}{l}\text { Pre } \\
\text { Test }\end{array}$ & 21 & 14 & 7 & $66,67 \%$ & $33,33 \%$ \\
\hline & $\begin{array}{l}\text { Post } \\
\text { Test }\end{array}$ & 20 & 4 & 16 & $20,00 \%$ & $80,00 \%$ \\
\hline
\end{tabular}

Tabel 2. Perbandingan Persentase Hasil Belajar Akuntansi Siswa

Berdasarkan tabel di atas, perbandingan hasil belajar akuntansi siswa pada siklus I dan siklus II disajikan pada grafik berikut ini: 


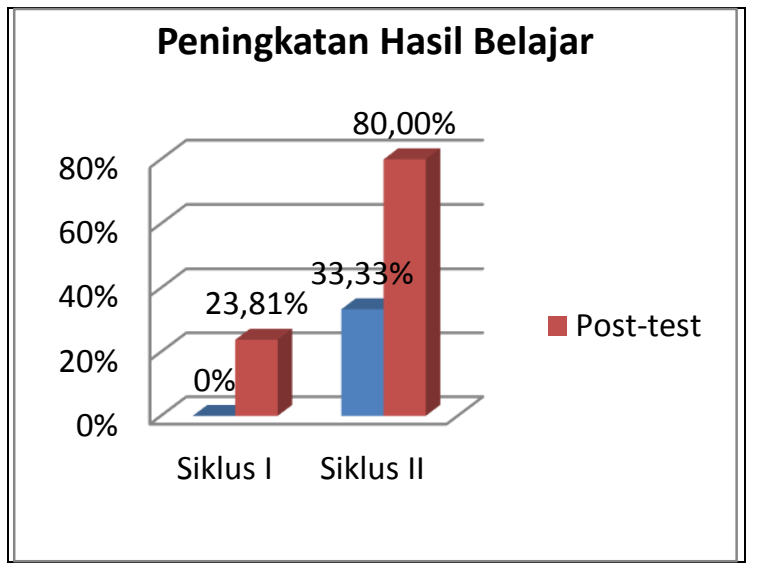

\section{Gambar 2. Grafik Perbandingan Hasil Tes Siswa}

Berdasarkan data di atas diketahui bahwa pada pre-test siklus I tidak ada siswa yang mencapai nilai KKM, setelah dilaksanakan kegiatan pembelajaran dengan Model Pembelajaran Kooperatif Teknik Jigsaw Berbantu Media Kartu, siswa mencapai KKM menjadi 5 siswa atau $23,81 \%$. Siklus II juga mengalami peningkatan. Berdasarkan pre test siswa yang mencapai KKM sebesar 33,33\% atau sebanyak 7 siswa, dan pada post test mencapai $80,00 \%$. Berdasarkan hal tersebut,maka Hasil Belajar Akuntansi mengalami peningkatan sebesar $56,19 \%$. sebesar $53,13 \%$.

\section{KESIMPULAN DAN SARAN Kesimpulan}

Berdasarkan hasil penelitian dan pembahasan pada bab IV dapat disimpulkan bahwa

a. Penerapan Model Pembelajaran Kooperatif Teknik Jigsaw Berbantu Media Kartu dapat meningkatkan Aktivitas Belajar siswa. Hal ini dapat dibuktikan dengan adanya peningkatan untuk masing-masing indikator Aktivitas Belajar siswa yang meliputi tujuh indicator. Aktivitas Belajar siswa berdasarkan hasil observasi meningkat dari siklus I sebesar 53,89\% meningkat menjadi
$77,27 \%$ pada siklus II dan 20 siswa atau $90,91 \%$ siswa mengalami peningkatan skor Aktivitas Belajar.

b. Penerapan Model Pembelajaran Kooperatif Teknik Jigsaw berbantu Media Kartu dapat meningkatkan Hasil Belajar Akuntansi siswa. Peningkatan tersebut dapat dibuktikan dengan hasil penelitian yang berupa soal pre test dan post test. Hasil Belajar Akuntansi siswa dari post test siklus I ke post test siklus II mengalami peningkatan dan sudah menunjukkan ketercapaian keberhasilan tindakan yang diharapkan. Siswa yang mencapai nilai Kriteria Ketuntasan Minimal (KKM) lebih dari $75 \%$ yaitu 5 siswa atau $23,81 \%$ pada siklus I menjadi 16 siswa atau $80,00 \%$ pada siklus II. Siswa yang mengalami peningkatan Hasil Belajar Akuntansi sebesar $56,19 \%$.

\section{Saran}

\section{BagiGuru}

a. Model Pembelajaran Kooperatif Teknik Jigsaw Berbantu Media Kartu dapat diterapkan oleh guru sebagai variasi model pembelajaran agar siswa tidak bosan. Model pembelajaran ini dapat membuat siswa lebih aktif dalam pembelajaran dan suasana belajar menjadi tidak membosankan.

b. Guru hendaknya memberikan lebih banyak waktu kepada siswa untuk berdiskusi di kelompok asli maupun kelompok ahli sehingga siswa dapat memperdalam pengetahuannya mengenai materi dan belajar untuk berani mengungkapkan pendapat kepada teman.

c. Guru sebaiknya memberikan rangsangan dan mendorong siswa untuk berfikir kritis dan aktif selama proses pembelajaran. Guru mendorong siswa untuk aktif 
bertanya maupun menjawab sesering mungkin.

\section{Bagi Peneliti Selanjutnya}

Model pembebelajaran ini dapat meningkatkan Aktivitas Belajar dan Hasil Belajar Akuntansi, bagi peneliti lain dapat mengembangkan penelitian ini dengan variasi yang berbeda seperti variabel yang berbeda, indikator yang berbeda, dan mata pelajaran yang berbeda.

\section{DAFTAR PUSTAKA}

Ahmed Riahi Balkaoui. (2000). Teori Akuntansi Edisi Pertama. Jakarta: Salemba Empat.

Anita Lie. (2008). Cooperative Learning: Mempraktikkan Cooperative Learning di Ruang-Ruang Kelas. Jakarta : Grasindo.

Arief S. Sardiman dkk. (2011). Media Pembelajaran: Pengertian, Pengembangan, dan Pemanfaatannya. Jakarta: Pustekom Dikbud dan PT. Raja Grafindo Persada.

E.Mulyasa. (2006). Kurikulum Berbasis Kompetensi Konsep, Karakteristik, Implementasi, dan Inovasi. Bandung: Remaja Rosdakarya

Made Wena. (2010). Strategi Pembelajaran Inovatif Kontemporer. Jakarta: Bumi Aksara.

Martinis Yamin. (2007). Kiat Membelajarkan Siswa. Jakarta: Gaung Persada Press Jakarta.

Miftahul Huda. (2013). Cooperative Learning Metode, Teknik, Struktur dan Model Penerapan. Yogyakarta: Pustaka Pelajar.
Muhibbin Syah. (2011). Psikologi Pendidikan dengan Pendekatan Baru. Bandung:Remaja Rosdakarya.

Nana Sudjana. (2005). Penilaian Hasil Proses Belajar Mengajar. Bandung: Remaja Rosdakarya.

(2010). Kurikulum Tingkat Satuan Pendidikan. Bandung: PT Remaja Rosdakarya.

Oemar Hamalik. (2011). Kurikulum dan Pembelajaran. Jakarta: Bumi Aksara.

Sardiman. (2011). Interaksi dan Motivasi Belajar Mengajar. Jakarta: Raja Grafindo Persada.

Slavin, Robert E. (2009).Cooperative Learning teori, riset, dan praktik. Bandung: Nusa Media.

Syaiful Bahri Djamarah dan Aswan Zain. (2010). Strategi Belajar Mengajar. Jakarta Rineka Cipta.

Trianto. (2010). Mendesain Model Pembelajaran Inovatif-Progresif: Konsep, Landasan, dan Implementasinya pada Kurikulum Tingkat Satuan Pendidikan (KTSP). Jakarta: Kencana Prenada Media Group.

Wina Sanjaya. (2009). Strategi Pembelajaran Berorientasi Standar Proses Pendidikan. Jakarta: Kencana Prenada Media Group.

Zainal Aqib. (2002). Profesionalisme Guru dalam Pembelajaran. Surabaya. Insan Cendekia. 